\title{
Ecology of tropical hermit crabs at Quirimba Island, Mozambique: distribution, abundance and activity
}

\author{
David K. A. Barnes* \\ Society for Environmental Exploration, 77 Leonard Street, London, United Kingdom \\ and Frontier Moçambique, Caixa Postal 19, Pemba, Cabo Delgado, Mozambique
}

\begin{abstract}
A diverse assemblage of 16 species of hermit crabs occurs on the shores of the Quirimba Archipelago, northern Mozambique. Each species illustrated marked zonation such that they formed a distinct sequence from the subtidal across the wide intertidal zone to the supra-littoral. In addition to shore height zonation, there was distinct variation in type and range of habitat preferences. Of the 5 study islands, Quirimba and Quisiva had the greatest intertidal habitat variety and the largest number of resident hermit crab species. The number of hermit crab species peaked at 10 in the lower-shore zone and decreased upshore to 3 supra-littoral species and downshore to 8 subtidal species. In contrast, the density of hermit crab individuals peaked in the upper mid-shore, at $3 \mathrm{~m}^{2}$ The mid-shore zone was also the primary region of cluster formation, principally involvang Clibanarius laevimanus and Clibanarius virescens, although 3 other species were also involved. The activity of the 2 semi-terrestrial species, Coenobita rugosus and Coenobita cavipes, on Quirimba Island was principally related to the light:dark cycle but was strkingly different between open and mangrove habitats. Some degree of activity took place in both species throughout a $24 \mathrm{~h}$ period in the mangrove habitat, where the peak of feeding activity was twice that of the open sand-scrub habitat. Wind strength was a major influence on the activity of $C$. rugosus and $C$. cavipes, reducing the number of active individuals to zero at higher wind speeds, even in thinly mangroved habitats.
\end{abstract}

KEY WORDS: Hermit crab - Intertidal · Diversity · Activity · Mangrove Africa

\section{INTRODUCTION}

Hermit crabs have held particular interest amongst ecologists worldwide for many years and thus have been a particularly well-studied group of crustaceans. Much of this work has focused on behavioural characteristics related to the use of molluscan shells by tropical intertidal species, and these studies have illustrated the complexity of shell selection with respect to shell species identity (Reese 1962, Young 1979, Wilber 1990), shell geometry, size and damage (Vance 1972, Conover 1978. Taylor 1981), presence of shell symbionts (Jensen 1970. Mercando \& Lytle 1980) and associated agonistic behaviour (Hazlett 1966, 1972). Furthermore, the availability of shells has been shown to

\footnotetext{
-Address for correspondence: Department of Zoology and Animal Ecology, Unuversity College Cork, Lee Maltıngs,

Cork, Ireland. E-mail: dkab@ucc.ie
}

be an important constraint on many hermit crab populations (Provenzano 1960, Hazlett 1970, Kellogg 1976 , Bertness 1980), although occasionally shells have been found to be abundant (MacGinite 1955, Markham 1968). Recent studies of a particularly characteristic and complex activity exhibited by a number of species has revealed another shell-related behavioural trait. The large gatherings of individuals, termed clustering, are now thought to be geared around shell exchange (Gherardi 1990, Gherardi \& Vannini 1993). Other lessshell-related activities, such as predator interactions (Ross 1971), migrations and digging behaviour (Vannini 1975,1976 ), have also been studied in a few species. Although East Africa has been, and remains, one of the major areas for many of these investigations, there have been virtually no studies of hermit crabs in central or northern Mozambique since the preliminary species lists of Hilgendorf (1878).

Despite being over $2700 \mathrm{~km}$ in length, the coastline and associated nearshore marine environment of 
Mozambique remain relatively poorly known in comparison with those of other East African or tropical states worldwide. The lengthy period of internal conflict ending in 1992 effectively restricted marine research (along with virtually all other disciplines) by internal and external scientists to the southern island of Inhaca close to the capital city of Maputo. Studies at the marine biological station on Inhaca Island have shown diverse intertidal assemblages of crustaceans, including Anomura (hermit crabs), and many other taxa (Kalk 1958, 1959, MacNae \& Kalk 1962, 1969, Longomane 1995, Macia 1995). As at Inhaca Island, the intertidal of other populated areas is a vital resource to a predominantly coast-dwelling and poor population, perhaps nowhere more so than in the Quirimba Archipelago in the far north of the country (D. K. A. Barnes, A. Corrie, M. Whittington, M. A. Carvelho \& F. Gell unpubl. data). The tropical archipelago of low lying islands is in a region where the shelf and intertidal zones are very wide (about $4 \mathrm{~km}$ in places) and a variety of habitats are encompassed in addition to the extensive coral reefs on the eastern seaboards.

A large number of hermit crab species are known to occur throughout the variety of East African regions and littoral habitats (Hilgendorf 1878, MacNae \& Kalk 1969, Lewinsohn 1982, Macia 1995). The study described here forms one of a series describing the ecology of hermit crab species occurring at one of the most remote mainland locations in East Africa. This study reports on the variety of anomuran species found in the intertidal and immediate subtidal of 5 of the southernmost islands of the Quirimba Archipelago. Some aspects of their distribution, abundance and activity are also investigated. This work forms part of the marine research programme of the Darwin/Frontier Moçambique project, of the Society for Environmental Exploration and the Ministépara a Coordenação de Acção Ambiental (Maputo, Mozambique).

\section{METHODS}

Various aspects of tropical hermit crab ecology were studied on 5 low-lying, nearshore islands of the Quirimba Archipelago, in the Cabo Delgado province in northern Mozambique, East Africa (Fig. 1). The work was carried out from the field survey camp of Frontier Moçambique on the central island of Quirimba between May and August 1996. Most of the work was carried out on Quirimba Island itself, but the distribution and abundance of hermit crabs on Quisiva, Quilaluia, Mefunvo and Sencar islands was examined for comparative purposes. The study areas of the islands were divided into 4 shore zones and 1 subshore zone. The subshore zone was termed (conventionally) the subtidal. The zone above this, the lower-shore zone, was defined as spanning the area between the Extreme Low Water Spring tide level (ELWS) and that reached after $2 \mathrm{~h}$ from low water ( $1 / 3$ time between low and high water). The mid-shore zone was defined as that between $2 \mathrm{~h}$ and $4 \mathrm{~h}$ after low water $(1 / 3$ to $2 / 3$ time between low and high water). The upper-shore zone was defined as that between $4 \mathrm{~h}$ after low water and the Mean High Water level (MHW), and lastly the supra-littoral zone was defined as that between MHW and the splash zone above the Extreme High Water Spring tide level (EHWS).

The diversity and distribution of hermit crab species was assessed using multiple quadrats $\left(05 \mathrm{~m}^{2}\right)$ every $10 \mathrm{~m}$ along transects from the ELWS to the EHWS. Transects were sited to incorporate all the major intertidal habitats (coral reef, sandflat, sand overlyıng rock, rock, seagrass meadow, and fringe and deep mangrovesj of each of the 5 islands surveyed. In addition to the transect method, a $5 \mathrm{~m}$ wide swathe was observed by walking a zigzag pattern between the lower-shore and supra-littoral zones around the crrcumference of each istand. The uunver dnd doentufication of ail crab species present were recorded for each tıdal zone. The

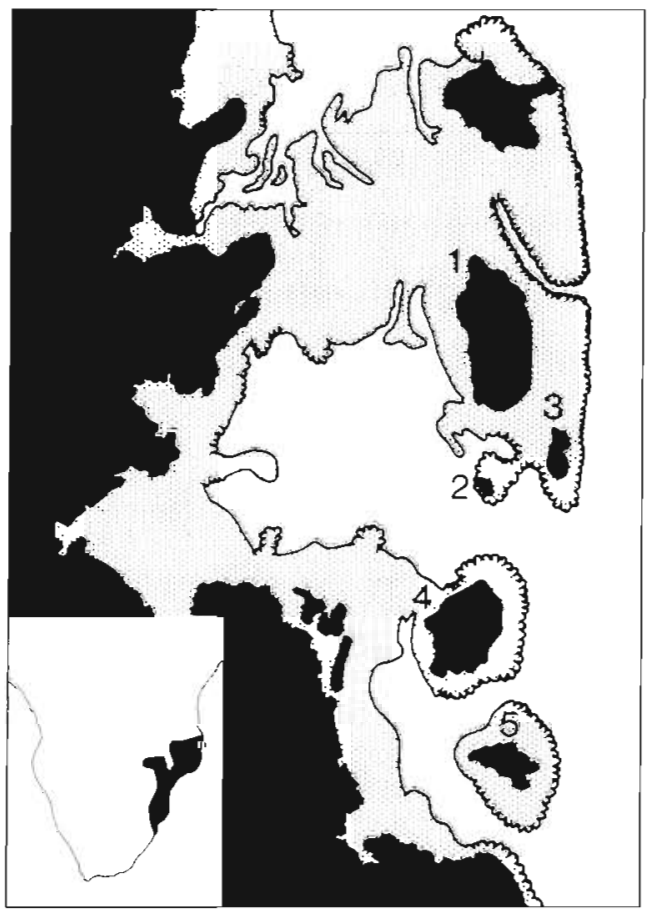

Fig. 1. Insert, bottom left. the position of Mozambique in southern Africa and that of the Quirmba Archipelago in northern Mozambique Maın map $40 \mathrm{~km}$ of coast showing the position of the 5 study islands in the Quimmba Archipelago. The islands are: 1. Quirumba, 2, Qulaluia, 3, Sencar, 4. Mefunvo; and 5, Quisiva The light shaded area represents the intertidal and shallows, with a smooth edge denoting sand and a jagged edge coral reef 
maximum abundance of each species $\left(\mathrm{m}^{-2}\right)$ was established by combining the results of the 2 methods. The distribution and abundance of subtidal species were assessed using similar survey methods with SCUBA in $5 \mathrm{~m}$ water depth (from Mean Low Water tide level, MLW).

The abundance of each species was scored according to the maximum population density (ind. observed $\mathrm{m}^{-2}$ ) in 5 categories: super abundant, $>10 \mathrm{~m}^{-2}(\mathrm{SA})$;

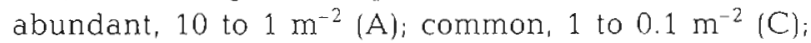
occasional, 0.1 to $0.01 \mathrm{~m}^{-2}(\mathrm{O})$; and present, $<0.01 \mathrm{~m}^{-2}$ (P). The numbers of hermit crab species were compared and summed within each zone such that the approximate proportion each species contributed to zonal populations could be calculated. The supralittoral zone was further subdivided (into 4 zones) according to the number of horizontal meters (distance) from the high water level. The numbers and identities of hermit crabs were then counted in each of the 4 subzones to establish within-zone species population changes.

Additional ecological information was collected simultaneously to allow division of hermit crab ecology by habitat, separate from tidal zoning and study of behavioural aspects of distribution such as clustering. The nature, composition and shore position of 30 hermit crab clusters on Quirimba Island were also examined. The number and identity of all species were recorded as well as the total number of individuals. Similar features of clusters were casually observed on other islands for between-island comparisons.

The periodicity, duration and types of activities were observed for all the locally common hermit crab species on Quirimba Island. Particular attention was paid to the supra-littoral species, partly because of increased complexity of activity and governing influences and partly because of ease of study. The number of active individuals of 2 species of supra-littoral hermit crab, Coenobita rugosus and C. cavipes, were monitored in 3 study areas of $4 \mathrm{~m}^{2}$. The 3 study areas encompassed 3 of the 4 locally characteristic supralittoral habitats, sand-scrub, thin 'fringe' mangrove and thick 'deep' mangrove. Hermit crabs were observed to be absent from the remaining supra-littoral habitat of vertical/overhanging rock and so this habitat was excluded from detailed study. In the habitats where populations of the 2 species overlapped, the activity of individuals was observed and classified into either crawling, feeding or burrowing/climbing types. Quantification of each activity type was scored by the proportion of the total population involved in each activity within the observation plot at the time of the reading The total active population was also recorded at maximum intervals of $1 \mathrm{~h}$ (sometimes every $1 / 2 \mathrm{~h}$ ) for a 24 h period.
The 24 h study, described above, was used in interpretation of the influence of time on population activity. Other influences on the activity of Coenobita rugosus and Coenobita cavipes populations were investigated by monitoring population densities in the three $4 \mathrm{~m}^{2}$ study sites over a period of $6 \mathrm{wk}$. Total activity of both species was recorded at 8:00 and 20:00 h each day to study the effect of low/high and spring/ neap tidal cycles and variation in habitat, individual size and wind strength. Wind strength was measured in units of the Beaufort scale.

\section{RESULTS}

\section{Diversity and distribution}

A total of 16 species of hermit crab were found in the intertidal and immediate subtidal zones of islands of the Quirimba Archipelago. Two species of the family Coenobitidae were present, Coenobita rugosus and Coenobita cavipes, and these were associated with upper reaches of sand shores and mangroves. Twelve species were diogenids from the genera Clibanarius, Calcinus, Diogenes, and Dardanus, and the remaining 2 species were pagurids from the genera Eupagurus and Trizopagurus. Clibanarius longitarsus mostly occurred in and around the seaward margin of mangroves, and Clibanarius laevimanus and Clibanarius virescens were mainly found on fine sand with underlying and outcropping reef rock areas, although $C$. virescens was also common in the seagrass meadows. Calcinus laevimanus, Calcinus latens, Diogenes senex, Diogenes sp. and Eupagurus sp. also mainly occurred in the seagrass meadows, but both Calcinus species occasionally occurred on fine sand/reef rock areas. Trizopagrus strigatus and Dardanus pedunculatus were only found on reef crests or in the associated lagoons enclosed by reef crests. The remaining 4 species found in this study, Dardanus megistos, Dardanus guttatus, Dardanus deformis and Dardanus lagopodes, were principally subtidal, but $D$. megistos occasionally occurred in the lower regions of the seagrass meadows

Twelve of the total 16 species of hermit crab were found on the intertidal zones of Quirimba and Quisiva islands, and 6 of these 12 were found on all 5 of the study islands (Table 1). Of the islands studied, the intertidal areas of Quirimba and Quisiva islands were the most diverse, encompassing some of all the above mentioned habitats. The fewest species of hermit crab were found on the smallest island, Quilaluia, which had the smallest intertidal area and smallest range of habitats. The number of species on the intertidal of each island was, therefore, not surprisingly related to the diversity of habitats supported. The individual spe- 
Table 1. Hermit crab species presence and abundance on islands of the Quirimba Archipelago. The levels of abundance are $\mathrm{SA}$, super abundant $\left(>10 \mathrm{~m}^{-2}\right)$; A, abundant $\left(10-1 \mathrm{~m}^{-2}\right)$; C, common $\left(1-0.1 \mathrm{~m}^{2}\right) ; \mathrm{O}$, occasional $\left(0.1-0.01 \mathrm{~m}^{-2}\right)$ and P, present $\left(<0.01 \mathrm{~m}^{-2}\right)$. Subtidal species present in the Qurrimba Archipelago are listed as na (not applicable)

\begin{tabular}{|lcccccc|}
\hline \multirow{2}{*}{$\begin{array}{l}\text { Hermit crab } \\
\text { species }\end{array}$} & \multicolumn{5}{c}{ Island } \\
\cline { 2 - 6 } & Quirimba & Quilaluia & Quisiva & Mefunvo & Sencar \\
\hline Coenobita cavipes & SA & - & $\mathrm{P}$ & $\mathrm{P}$ & $\mathrm{C}$ \\
Coenobita rugosus & $\mathrm{SA}$ & $\mathrm{C}$ & $\mathrm{A}$ & $\mathrm{A}$ & $\mathrm{A}$ \\
Clibanarius longitarsus & $\mathrm{A}$ & - & - & $\mathrm{C}$ & $\mathrm{A}$ \\
Clibanarius laevimanus & $\mathrm{SA}$ & $\mathrm{A}$ & $\mathrm{O}$ & $\mathrm{A}$ & $\mathrm{C}$ \\
Clibanarius virescens & $\mathrm{SA}$ & $\mathrm{SA}$ & $\mathrm{A}$ & $\mathrm{C}$ & $\mathrm{C}$ \\
Calcinus latens & $\mathrm{A}$ & $\mathrm{A}$ & $\mathrm{C}$ & $\mathrm{P}$ & $\mathrm{C}$ \\
Calcinus laevimanus & $\mathrm{A}$ & $\mathrm{A}$ & $\mathrm{O}$ & $\mathrm{SA}$ & $\mathrm{C}$ \\
Diogenes senex & $\mathrm{C}$ & $\mathrm{P}$ & $\mathrm{O}$ & $\mathrm{P}$ & - \\
Diogenes sp. & $\mathrm{O}$ & - & $\mathrm{O}$ & - & $\mathrm{P}$ \\
Eupagurus sp. & $\mathrm{P}$ & - & $\mathrm{P}$ & - & - \\
Trizopagurus strigatus & - & - & $\mathrm{P}$ & - & $\mathrm{P}$ \\
Dardanus megistos & $\mathrm{P}$ & $\mathrm{P}$ & $\mathrm{P}$ & $\mathrm{P}$ & $\mathrm{P}$ \\
Dardanus pedunculatus & $\mathrm{P}$ & $\mathrm{P}$ & $\mathrm{P}$ & $\mathrm{P}$ & - \\
Dardanus guttatus & na & na & na & na & na \\
Dardanus deformis & na & na & na & na & na \\
Dardanus lagopodes & na & na & na & na & na \\
\hline
\end{tabular}

littoral. In regions of the supra-littoral zone with mangroves, C. cavipes dominated, whereas in sand-scrub regions C. rugosus dominated assemblages. In regions with only thin mangroves (denoted fringe in this study) separating the 2 habitats, a complex assemblage pattern showed C. cavipes dominating the mid regions of the supra-littoral zone and $C$. rugosus dominating the upper regions

\section{Abundance}

Hermit crabs were the most abundant taxon of macro-crustaceans in any habitat or zone of the intertidal and of ail of the 5 islands studied, with one exception: hermit crabs were absent from the parts of the uppershore/supra-littoral zone formed by vertical àīa overilanyiny lock ciirîs,

cies present were related to which particular habitats were present. Thus on islands where there was, for example, either very little or no mangrove present (Quisiva and Quilaluia), mangrove dependent species such as Clibanarius Iongitarsus were absent. Some species, such as Trizopagurus strigatus and Eupagurus $\mathrm{sp}$. were comparatively rare and may have occurred on all the study islands but were recorded only where chance findings occurred.

The hermit crab species studied had clearly defined zonation up the shore from the subtidal to the supra-littoral zones (Table 2). The highest number of species (10) occurred on the lowershore, declining to 8 subtidally and 3 on the upper-shore and supra-littoral. No one species was found throughout all 5, or even 4, of the shore zones studied, but the 3 Clibanarius species and Calcinus laevimanus were present in 3 of the 5. Within the supra-littoral zone there were marked differences in distribution amongst the 3 species present, Coenobita cavipes, Coenobita rugosus and Clibanarius longitarsus, according to habitat and shore height (Fig. 2). The lower region of the supralittoral zone was dominated by $C$. longitarsus, but with increasing distance up the shore Coenobita species increased, and $C$. longitarsus was absent from the upper regions of the supra- which were characterised by grapsid crabs. The total abundance of hermit crabs across the intertidal region of Quirimba Island increased by more than an order of magnitude from the ELWS to a mid-tidal level before decreasing towards the EHWS (Fig. 3). Overall the most abundant species were Clibanarius laevimanus, Clibanarius virescens and Calcinus laevimanus, which together accounted for approximately $75 \%$ of all intertidal hermit crabs. The abundances of some hermit

Table 2. The population proportions of littoral and subtidal zone hermit crab species at Quirimba Island. The values shown are approximate population percentages from estimates using multiple quadrat technique. "Zones occupied on Quisiva Island; not present on Quirimba Island, so no data available

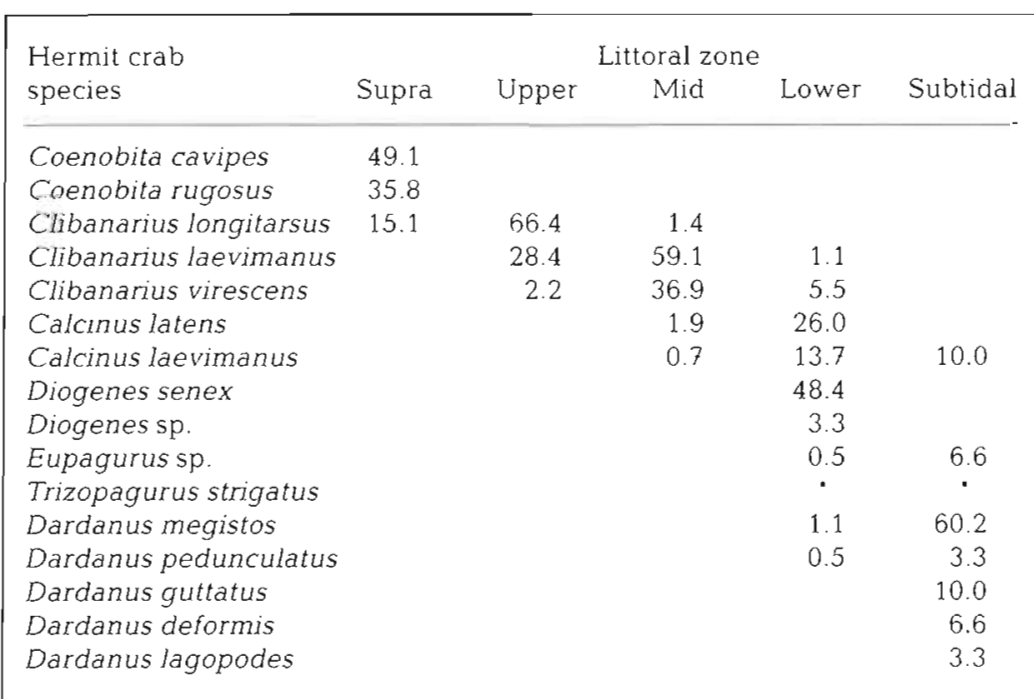



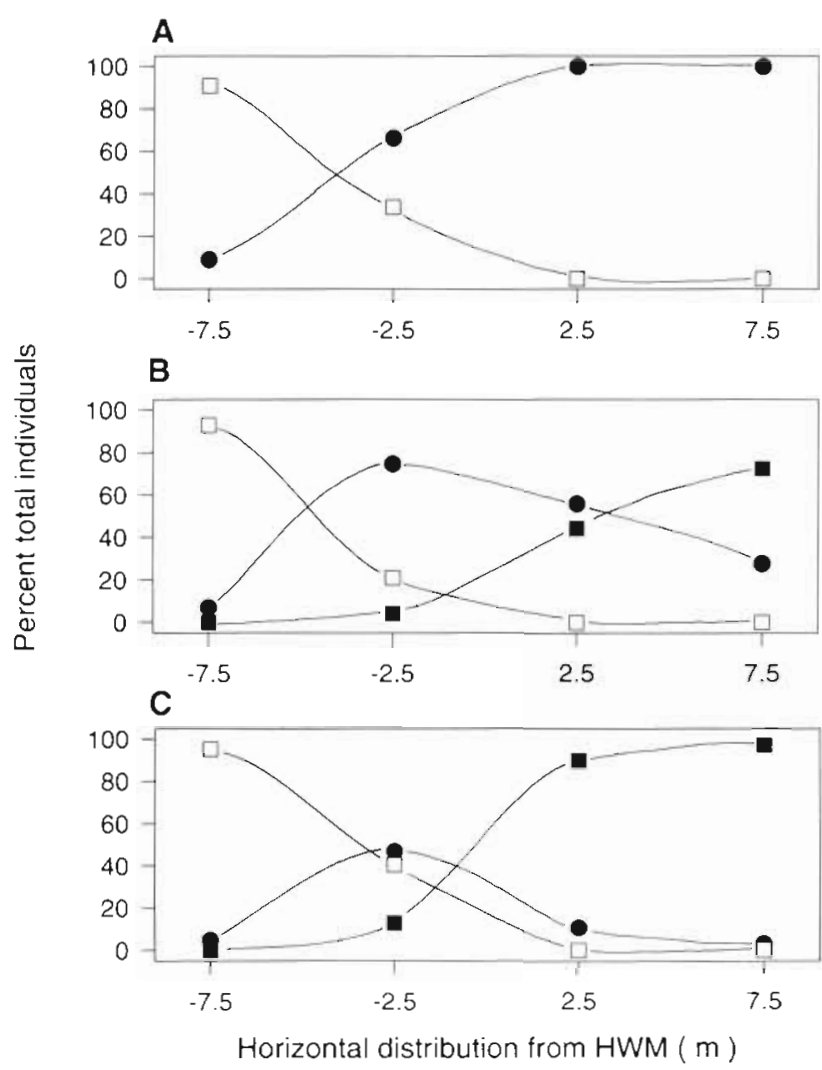

Fig. 2. Coenobita cavipes (-), C. rugosus (E), and Clibanarius longitarsus ( $\square$ ). Population proportions of hermit crab species with distance from the High Water tidal Mark (HWM) in the supra-littoral zone of Quirimba Island in (A) deep mangrove, (B) fringe mangrove, and (C) sand-scrub (non-mangrove) habitats

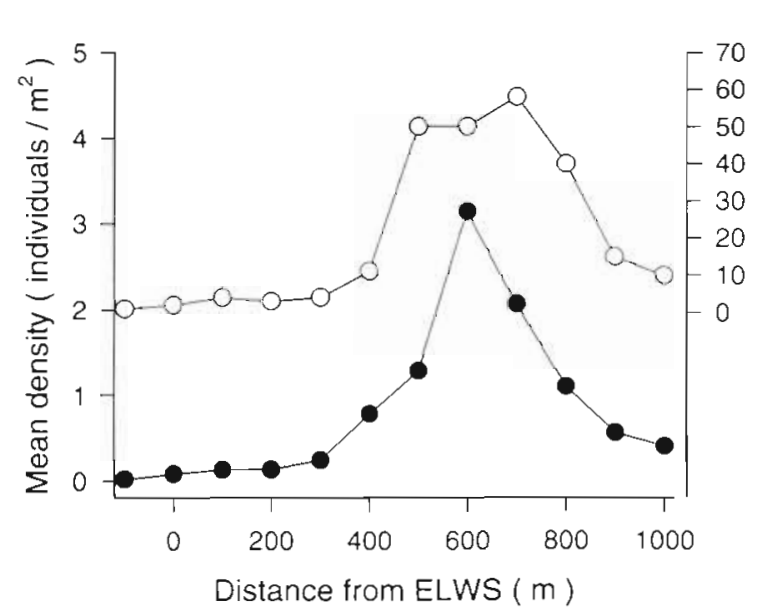

Fig. 3. Total abundance of hermit crabs across the shore at Quirimba Island. Values represent the combined density of all species from the immediate subtidal region (negative) to $1000 \mathrm{~m}$ (EHWS) from the ELWS level. Plots show ( $)$ mean and $(0)$ maximum densities. Curves are fitted by eye crab species altered considerably between islands (Table 1). Other species, notably the supra-littoral zone Coenobita rugosus, the mid-shore $C$. virescens and the lower-shore Dardanus megistos, were broadly similar in abundance across the islands studied. Whilst the intertidal distributions of most species spanned more than 1 shore zone, their abundances varied considerably between such zones (Table 2). In all the study species there was a marked peak of abundance confined to a particular shore zone. In the mid-shore zone the most abundant species, and to a lesser extent some of the other hermit crab species present, adopted the popularly studied behavioural trait of clustering

\section{Clustering}

Mid-shore clusters of hermit crabs (with occasional living molluscs as well) were usually formed on the highest local ground. Where the mid-shore was characterised by fine sand/overlying and outcropping reef rock, clusters occurred on the high and sharp rock ridges caused by differential erosion. The main species which formed clusters were Clibanarius laevimanus and Clibanarius virescens, but Clibanarius longitarsus and both Calcinus species were also present occasionally. For most clusters, more than $90 \%$ of the hermit crabs present represented 1 species, and 11 out of 30 clusters examined were composed entirely of a single species ( 4 out of 30 were formed of 3 species and the remainder of 2 species). The species dominating clusters was generally Clibanarius laevimanus on the upper mid-shore and $C$. virescens on the lower mid-shore of Quirimba Island. On the mid-shore of Mefunvo island, in contrast, most of the clusters were dominated by $\mathrm{Cal}$ cinus laevimanus. Clusters were usually formed of hermits occupying similar shell identities (from the same mollusc species) and of similar size. The clusters examined varied considerably in size from 105 to 1104 individuals, but were constantly changing with time and tide, and hence difficult to compare. The largest cluster sizes studied were all formed of small individuals and, although normally 3 or 4 individuals high, occasionally formed spires up to 7 individuals high. The supralittoral zone species Coenobita cavipes and Coenobita rugosus formed smaller gatherings, but these pseudoclusters differed from those typically described as they involved no period of dormancy and were usually cases of gregariousness around large food items.

\section{Periodicity, duration and type of activity}

The periodicity of activity, other than clustering to become dormant (above), of most of the study species 
C. rugosus

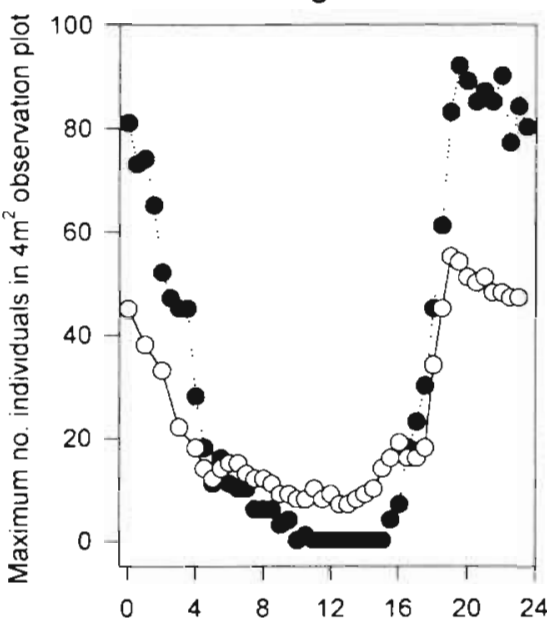

C. cavipes

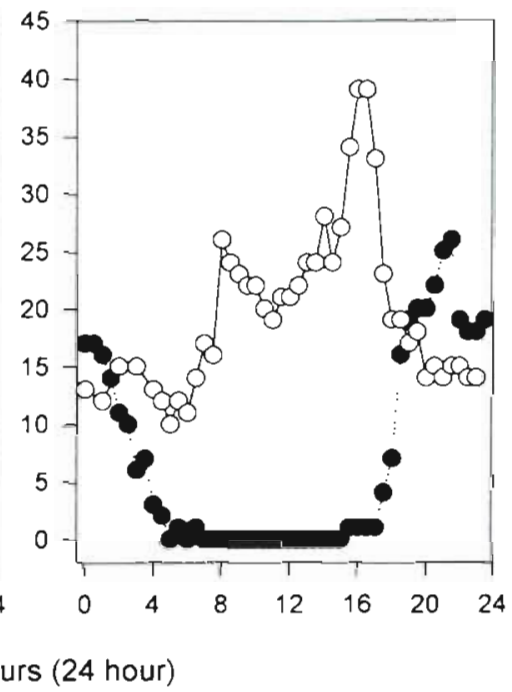

Fig. 4. Coenobita rugosus and $C$. cavipes. Population change with time over a $24 \mathrm{~h}$ period, in (O) fringe mangrove and sand-scrub (non-mangrove) habitats. High water was at approximately $01: 40$ and 14:20 h, low water was at approximately $08: 00$ and 20:40 h. Note the different scales of the $y$-axes for the plots of the 2 species

was confined to periods of immersion and, therefore, to the higher phases of the tide. The activity in the supralittoral zone of the semi-terrestrial species Coenobita cavipes and $C$. rugosus, however, was almost entirely confined to areas above the water level. Whilst there was much variation in activity level of $C$. cavipes and C. rugosus, there was at least some degree of activity observed from populations of both species throughout a 24 h period (Fig. 4). The level of activity (measured in terms of number of active individuals per $4 \mathrm{~m}^{2}$ observation plot) of $C$. rugosus reached a peak at about 19:00 h, shortly after sunset, with little activity during the day. The activity and behaviour of $C$. cavipes were, however, more complex. In the sand-scrub habitat, the activity pattern of $C$. cavipes resembled that of $C$.

Table 3. Coenobita cavipes and C. rugosus. Mean (SE) activity with tidal state. Data is displayed as the number of active individuals per $4 \mathrm{~m}^{2}$ observation plot $(\mathrm{n}=9$ ). The values for high and low water at 08:00 and 20:00 h ( $\pm 30 \mathrm{~min}$ ) are compared within species (intraspecifically) to produce $T$-values. In all cases the means are not significantly different at the $p=0.05$ level

\begin{tabular}{|c|c|c|c|c|}
\hline \multirow{2}{*}{ Species } & \multirow{2}{*}{ Time (h) } & \multicolumn{2}{|c|}{ Tidal state } & \multirow{2}{*}{$\begin{array}{c}\text { Significance } \\
\text { ( } T \text {-value })\end{array}$} \\
\hline & & High & Low & \\
\hline \multirow{2}{*}{ C. cavipes } & 08:00 & $5.00(0.58)$ & $4.89(0.54)$ & 9.08 \\
\hline & $20: 00$ & $5.44(1.50)$ & $4.25(0.45)$ & 3.63 \\
\hline \multirow[t]{2}{*}{ C. rugosus } & 08:00 & $2.89(1.07)$ & $3.13(0.70)$ & 4.04 \\
\hline & $20: 00$ & $12.7(2.46)$ & $12.29(2.13)$ & 5.07 \\
\hline
\end{tabular}

rugosus though with reduced densities and a greater period of inactivity. Both the general level and peak of $C$. cavipes activity were considerably higher in the fringe mangrove habitat. In contrast to the pattern of activity in the sand-scrub habitat, 2 daylight peaks of activity occurred, the highest at about 16:00 h

Activities observed in Coenobita cavipes and $C$. rugosus took a number of forms, feeding, crawling, climbing, burrowing and shell inspection/ exchange. The majority of active time was spent crawling, and to a lesser extent feeding (Fig. 5), whilst few individuals were observed to be involved in climbing, burrowing or shell exchange per unit time. The peak of crawling activity around 16:00 h (Fig. 5) was principally down the beach to the high water mark (HWM) or water's edge Some larger C. cavipes individuals were observed to rrawl over $100 \mathrm{~m}$ over a couple of hours, usually around or shortly after dusk. C. rugosus individuals were not observed to travel more than $30 \mathrm{~m}$ in an activity cycle. The decrease in crawling activity was associated with a slow drift back up the beach, which was much less synchronous than the initiation of activity. The proportion of the C. cavipes study population feeding was apparently much higher than that of $C$. rugosus. Periods of inactivity were spent in tree branches, tree hollows, shallow sand burrows or rock crevices. In 1 rock crevice, 1 individual became stuck during the study period and trapped 3 other individuals also using the same refuge, subsequently causing their deaths.

\section{Influences on activity}

There were a number of obvious potential influences on the periodicity, duration and type of activity of Coenobita cavipes and C. rugosus: tidal state (high/ low and spring/neap), time, habitat, weather and individual maturity. Tidal state, either as the semidiurnal or biweekly cycle, proved to have no significant major influence on the activities of the study populations of either species (Table 3). The magnitude of spring tides (as opposed to neap tides) did have minor influences in the form of the amount of debris and potential food brought in and on the distances needed to travel to reach this strandline (HWM). Another minor influence of tide was on the distribution of the activity peaks of the 2 species: $C$. cavipes at HWM and $C$. 


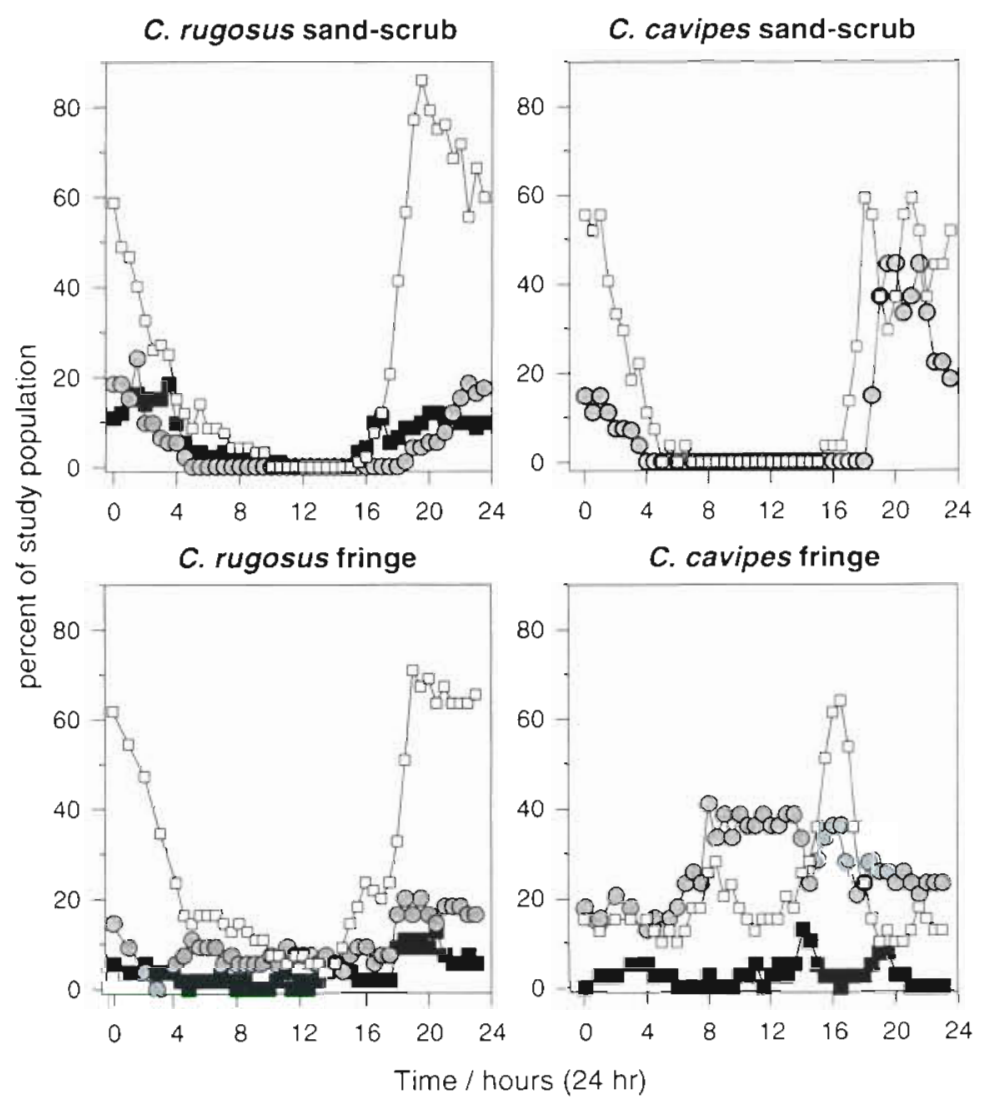

Fig. 5. Coenobita rugosus and C. cavipes. Activity types and population proportion in sand-scrub and fringe mangrove habitats. High water was at approximately $01: 40$ and $14: 20 \mathrm{~h}$, low water was at approximately 08:00 and 20:40 h. Activities are ( $\square$ ) crawling, (O) feeding and ( $\square$ ) burrowing/climbing. No burrowing or climbing was observed within the experimental $4 \mathrm{~m}^{2}$ observation plot for $C$. cavipes in the sand-scrub habitat (thus no plot is shown)

rugosus at $10 \mathrm{~m}$ above HWM. Some influences of both time and habitat are clearly illustrated by Figs. $4 \& 5$. C. rugosus showed a largely nocturnal pattern of activity, with a slightly increased amount of diurnal activity in a fringe mangrove habitat compared to that in sand-scrub. C. cavipes exhibited a similar, though more strongly nocturnal, pattern of activity to C. rugosus in the sand-scrub shore but a strongly contrasting pattern in the fringe mangrove habitat. The twin peaks of activity midway between midday and sunrise/sunset show a largely diurnal pattern of activity for the studied $C$. cavipes in mangroves. The activity patterns exhibited by $C$ cavipes were considerably more complex than those of $C$. rugosus. In addition to the differences between habitat, casual observations suggested large individuals of $C$. cavipes were more nocturnal, feeding at or below HWM, whereas smaller individuals were generally more diurnal, feeding at or above HWM.
The measurement of weather as an influence was restricted to wind speed (this being the major meteorological variable at Quirimba Island). Increased wind speed had little influence until or beyond force 2 (Beaufort scale), above which a negative influence on activity was suggested, but the degree of variation was high (Fig. 6). Although the nocturnal activity of Coenobita rugosus was significantly reduced by wind in both sandscrub (ANOVA, $F=10.5, p<0.05$ ) and fringe mangrove (ANOVA, $F=12.9, p<0.05$ ) habitats, the effect on the diurnal activity of the species is merely suggestive not significant (ANOVAs, $F=8.2, \mathrm{p}=0.07$ and $F=2.9, \mathrm{p}=$ 0.18 respectively). There is little evidence that the activity of C. cavipes was influenced in either the sheltered habitats of fringe or deep mangrove study areas, but it was significantly reduced nocturnally in the sandscrub habitat (ANOVA, $F=36.9, p<0.01$ ).

\section{DISCUSSION}

\section{Distribution and abundance of species}

Hermit crabs were extremely common on all 5 islands and on all shore habitats bar vertical rock surfaces. Anomurans dominated the macro-crustacean fauna, and in localised regions the whole macrobenthos, from the ELWS tide level to the upper supra-littoral level (above the EHWS tide level). As Hilgendorf found in the more northerly islands of the Quirimba Archipelago in 1878 , the present study of the southerly islands found extremely diverse hermit crab assemblages totalling 16 species. Up to 11 species were found on the intertidal of the 2 larger islands (plus 3 subtidal species), which had a greater variety of habitats than the 3 smaller islands. It is possible that a further 3 species, Clibanarius eurysternus, Calcinus tibicen and Aniculus sp., described from nearby Ibo Island (Hilgendorf 1878) are also present but were not found in the present study. Of the 5 littoral zones used in this study, the lower-shore zone had the highest species diversity (10 species from all habitats combined) but the lowest overall population density. The cause of such great diversity may stem from a variety of factors, including habitat variety, magnitude of intertidal zone, abundance and diversity of molluscs (as a shell resource), and low levels of anthropogenic disturbance (habitat damage or loss, pollution and possibly collection). In fact the local artisanal fisheries for mol- 


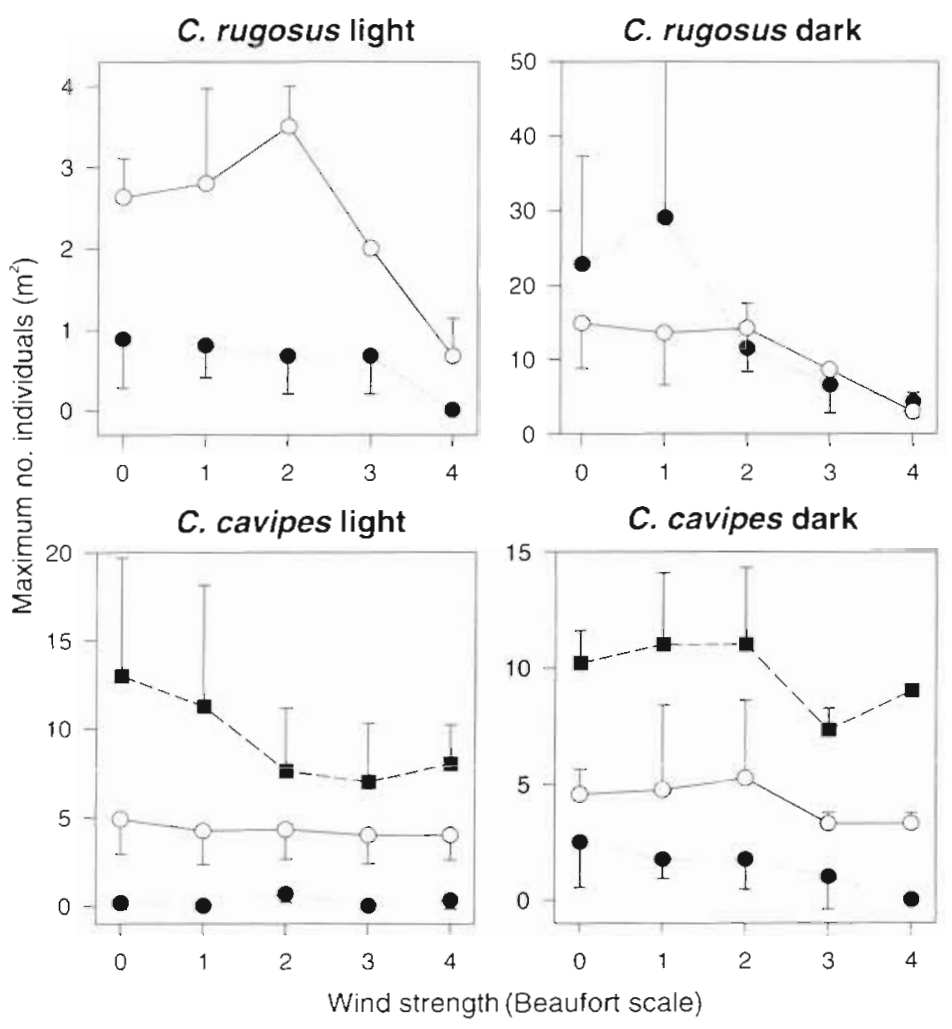

Fig. 6. Coenobita rugosus and C. cavipes. Population density (mean and SE) with wind strength and time in (-) sand-scrub (non-man-

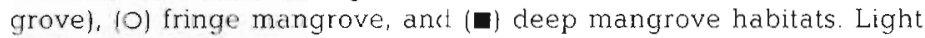
was defined as the period from sunrise to sunset, and dark the period from sunset to sunrise

luscs and the resultant practice of leaving piles of mostly undamaged shells on the upper-shore and supra-littoral may provide resource benefits to the larger individuals of hermit crab populations (Barnes et al. unpubl. data).

Most species occurred across more than 1 zone, but had distinct peaks of abundance in just 1 zone. Reese (1969), in discussing the relative importance of factors behind the macro- and micro-distribution of littoral zone hermit crabs, stressed the role of physiological tolerance to environmental extremes such as temperature, salinity and dehydration. These constraints are considered particularly important in locations where such conditions cannot be limited by behavioural adaptations. The exceptionally wide littoral zone of the Quirimba Archipelago (up to $4 \mathrm{~km}$ ) studied here is, with the exception of the mangrove areas, particularly exposed because of the hot and dry climate. In addition there must be large salinity fluctuations because of the proximity of several large river mouths and the large tidal movements associated with the size of the intertidal region. Gherardi (1990) found Calcinus ornatus and Clibanarius erythropus coexisting without compe- tition as a result of the lower physiological tolerance to environmental extremities of the former In this study species of the genera Calcinus and Clibanarius had zonal distributions which broadly differed in a respect similar to those of the representatives of the genera described by Gherardi (1990). The differences between genera distribution were more striking than species differences, from the supra-littoral zone through to the subtidal zone, Coenobita, Clibanarius, Calcinus, Diogenes, and Eupagurus/Trizopagurus/Dardanus peaked in abundance respectively.

The upper supra-littoral zone species, Coenobita cavipes and $C$. rugosus, have been widely reported from islands and mainland coasts throughout the Indo West-Pacific region over the last century (reviewed in Lewinsohn 1982). Vannini (1976) reported the 2 species occurring together in the same coastal habitats of Somalia, as found in this study; but, in contrast, Vannini found no distinct habitat preferences. Nore iypically $C$. iuyusus ilas been described as more inshore than $C$. cavipes (Alexander 1976, Burggren \& McMahon. 1988). In the Quirimba Archipelago it is clear that $C$. cavipes has a distribution linked principally to mangroves whilst $C$. rugosus occurs mostly on sandy shore areas, and they overlap at the fringe where the tree coverage is thin. Such differences in distribution have major implications for the variety, specific types and abundances of available molluscan shell resources (Barnes unpubl.).

The species which occurred on each island with similar abundances, Coenobita rugosus, Clibanarius laevimanus and Dardanus megistos, were unsurprisingly those which exhibited the widest tolerance of habitat variety. Some more-restricted species, e.g. Coenobita cavipes, still reached similar or greater levels of abundance through very high densities (mean up to $10 \mathrm{~m}^{-2}$ in localised parts of mangroves). Reduced predation pressure from fish, amongst other things, is probably a major reason for increased total abundance from ELWS to mid-shore.

\section{Activity}

The activity of most hermit crabs inhabiting the intertidal zone, regardless of latitude or longitude, has long been known to be almost entirely confined to periods of immersion, with the exception of the semiterrestrial species. Populations of the 2 semi-terrestrial hermit crab species observed in this study, 
Coenobita cavipes and C. rugosus, both exhibited activity of some form for the majority of the $24 \mathrm{~h}$ periods. Both species illustrated low points or dips in activity around 12:00 h (the hottest part of the day). but whilst $C$. rugosus was essentially nocturnal with residual or migrational activity stretching into the daylight side of either dusk and/or dawn, C. cavipes was more diurnal. Such striking differences in activity patterns are clearly dictated by habitat types and the elemental protection they confer. The population proportion of C. cavipes and C. rugosus feeding per unit time was low, peaking at $40 \%$ and $20 \%$ respectively. Most of the active period was spent crawling, $C$. cavipes travelling the greatest distances, but C. rugosus spending the most time engaged in crawling (Fig. 5).

The most marked difference in activity between those in mangrove and non-mangrove habitats was the length of time spent feeding in both species. The period spent eating in the mangrove habitat, typically Bruguiera gymnorhiza propagules and broken rootlets of various mangrove tree species, was more than double that in the sand-scrub habitat. Some of the increased crawling:feeding ratio in the sand-scrub habitat may be due to the greater scarcity of food items in the strandline, thus involving more search time, but the principal reason will be the increased travel to and from the burrow/crevice/tree daily shelter point. In addition to the daily migrations from resting to feeding locations studied here, Coenobita rugosus also undertakes periodical migrations of greater duration (Vannini 1976).

In addition to tide, time and habitat, another influence on hermit crab activity found to be important in the course of this study was wind strength. Whilst the degree of population variation was high (Fig. 6), wind strength may substantially reduce the activity of hermit crab populations. The hermit crabs of the sandscrub habitat, i.e. those with the least protection, were most affected. The influence of wind on activity was much greater on Coenobita rugosus than on $C$. cavipes, at least in part because the least-protected sand-scrub habitat is the main habitat of the former. Though why $C$. rugosus should be affected more than C. cavipes in the fringed mangrove habitat is not clear, as, if anything, $C$. rugosus would be expected to be more desiccation resistant since it inhabits the moreexposed environment. The mangrove habitat appears to confer a number of advantages in food supply, reduced foraging times and better elemental protection to C. Cavipes, but mangroves occupy only a small part of a few islands. Living in the more typical sandscrub habitat has undoubtedly allowed $C$. rugosus to colonise greater areas within each island and more islands of the archipelago.
Acknowledgements. The author thanks all the scientific staff, logistic staff and volunteer research assistants of the Darwin/Frontier Moçambique Marine Research Programme. This is a collaborative venture between the Society for Environmental Explorution (SEE) in the UK and the Ministépara a Coordenação de Acção Ambiental (MICOA) ın Mozambique and is partly funded by the Darwin Initiative for the Survival of Species (Department of the Environment, UK). I also thank Dr Peter Hogarth for help with identification and Dr Richard Hartnoll for advice. I am also very grateful to Damon StanwellSmith for being instrumental in the travel to Mozambique.

\section{LITERATURE CITED}

Alexander HGL (1976) An ecological study of the terrestrial decapod crustacea of Aldabra. PhD thesis, University of London

Bertness MD (1980) Shell preference and utılization patterns in littoral hermit crabs of the Bay of Panama. J Exp Mar Biol Ecol 48:1-16

Burggren WW, MCMahon BR (1988) Biology of the land crabs. Cambridge University Press, Cambridge

Conover MR (1978) The importance of various shell characteristics to the shell selection behaviour of hermit crabs. J Exp Mar Biol Ecol 32:131-142

Gherardi $F$ (1990) Competition and coexistence in two Mediterrancan hermit crabs, Calcinus ornatus (Roux) and Clibananus erythropus (Latreille) (Decapoda, Anomura). J Exp Mar Biol Ecol 143:221-238

Gherardi F, Vannini M (1993) Hermit crabs in a mangrove swamp: proximate and ultimate factors in the clustering of Clibananus laevimanus. J Exp Mar Biol Ecol 168:167-187

Hazlett BA (1966) Social behaviour of Paguridae and Diogenidae of Curacao. Stud Fauna Curacao Other Carbb Isl $23: 1-143$

Hazlett BA (1970) Interspecific shell fighting in three sympatric species of hermit crabs in Hawaij. Pac Sci 24 : $472-482$

Hazlett BA (1972) Shell fighting and sexual behaviour in the hermit crab genera Paguristes and Calcinus, with comments on Pagurus. Bull Mar Sci 22:806-823

Hilgendorf F (1878) Die von Hrn. W. Peters in Moçambique gesammelten Crustaceen. Monatsber. Akad Wiss Lit Manz Math-Naturwiss KI Mikrofauna Meeresbodens 25: $782-850$

Jensen K (1970) The interaction between Pagurus bernhardus (L.) and Hydrachtinia echinata (Fleming). Ophelia 8: $135-144$

Kalk $M$ (1958) The fauna of the intertidal rocks at Inhaca Island, Delagoa Bay. Ann Natal Mus 14:189-242

Kalk M (1959) The zoogeographic composition of the intertıdal fauna of Inhaca Island, Mozambique. S Afr J Sci 55: $178-180$

Kellogg CW (1976) Gastropod shells: a potentially limiting resource for hermit crabs. J Exp Mar Biol Ecol 22:101-111

Lewinsohn CH (1982) Researches on the coast of Somalia. The shores and the dunes of Sar Uanle. 33. Diogenidae, Paguridae and Coenobitidae (Crustacea, Decapoda, Paguridea). Monit Zool Ital 2:35-68

Longomane FA (1995) Exploração das Areas Entremarés Pela População Humana no Saco da lhla da Inhaca. Trabalho de Licenciatura. Universidade Eduardo Mondlane, Maputo, Mozambique

MacGinite GE (1955) Distribution and ecology of the marine invertebrates of Point Barrow, Alaska. Smithson Misc Collect 128:1-201 
Macia A (1995) Hermit crabs of the seagrass meadows around Inhaca Island, Moçambique, with emphasis on habitat and shell utilization. Unpubl PhD thesis, University of Goteborg

MacNae W, Kalk M (1962) The ecology of mangrove swamps at Inhaca Island, Mozambique. J Ecol 50:19-34

MacNae W, Kalk M (1969) A natural history of Inhaca Island, Moçambique. Wiwatersrand. University Press, Johannesburg

Markham JC (1968) Notes on growth patterns and shell utilization of the hermit crab Pagurus bernhardus. Ophelia 5:189-205

Mercando $N_{1}$ Lytle C (1980) Specificity in the association between Hydrachtinia echinata and sympatric species of crabs. Biol Bull Mar Biol Lab Woods Hole 159:337-348

Provenzano AJ (1960) Notes on Bermuda hermit crabs (Crustacea: Anomura). Bull Mar Sci Gulf Caribb 10:117-124

Reese ES (1962) Shell selection behaviour of hermit crabs. Anim Behav 10:347-360

Reese ES (1969) Behavioural adaptations of intertidal hermit crabs. Am Zool 9:343-355

This article was subinitted to the editor
Ross DM (1971) Protection of the hermit crab (Dardanus spp.) from Octopus by the commensal sea anemone (Calliactis spp.). Nature 230:401-402

Taylor R (1981) Hermit crab fitness: the effect of shell condtion and behavioural adaptations on environmental resistance. J Exp Mar Biol Ecol 52:205-218

Vance RR (1972) Competition and mechanisms of coexistence in three sympatric species of intertidal hermit crabs. Ecology 53:1062-1074

Vannini M (1975) Research on the coast of Somalia. The shores and dunes of Sar Uanle. 5. Description and rythmicity of digging behaviour. Monit Zool Ital 6:233-242

Vannini M (1976) Field observations on the periodical transdunal migrations of the hermit crab, Coenobita rugosus Milne Edwards. Monit Zool Ital 7:145-195

Wilber TP (1990) Influence of size, species and damage on shell selection by the hermit crab Pagurus longicarpus Mar Biol 104:31-39

Young A (1979) Differential utilization of gastropod shells by three hermit crab species in North Inlet, South Carolina, USA. Crustaceana 5:101-104

Manuscript received: December 3, 1996 Revised version accepted: March 3, 1997 